\title{
EVALUASI KESESUAIAN LAHAN UNTUK KAWASAN PERMUKIMAN DENGAN METODE MULTI CRITERIA EVALUATION DI KOTA PADANG
}

\author{
Evaluation for Suitability Land of Settletment Area by Using Multi Criteria Evaluation Method \\ in Padang
}

\author{
Iswandi Umara, Widiatmaka ${ }^{\mathrm{b}}$, Bambang Pramudya ${ }^{\mathrm{c}}$, dan Baba Barus ${ }^{\mathrm{d}}$ \\ aProgram Studi Geografi, Fakultas Ilmu Sosial UNP, Kampus Airtawar, Padang 25214 - iswandi_u@yahoo.com \\ ${ }^{b}$ Departemen Ilmu Tanah dan Sumberdaya Lahan, Fakultas Pertanian IPB, Kampus IPB Dramaga, Bogor 16680 \\ ${ }^{c}$ Departemen Mekanisasi Pertanian, Fakultas Teknologi Pertanian IPB, Kampus IPB Dramaga, Bogor 16680 \\ ${ }^{d}$ Departemen Ilmu Tanah dan Sumberdaya Lahan, Fakultas Pertanian IPB, Kampus IPB, Dramaga Bogor 16680
}

\begin{abstract}
Population growthis linear tothe requrement of settlement area, while the area of the earth is limited. It was caused inappropriate use of the land. This study aims to identify, analyze, and describe dynamics and suitability of land for settlements in Padang. Determination of land suitablity for settlementis using Multi Criteria Evaluation (MCE) method. The indicators used in determining the suitability of land for settlement is the slope, the frequency of flooding, drainage, distrubusi gravel, rock distribution and effective depth. Weighting in the analysis of land suitability based on the opinions of experts from various fields related to as many as 15 experts. Analysis result for land suitability of settlements in the area show that: there were 12.543 ha (18\%) very suitable for settlement; 52.390 ha $(75,4 \%)$ were suitable for settletment; 4.279 ha (6,2\%).were compatible with marginal for settlement; and 285 ha $(0,8 \%)$ were unsuitable for settlement. The area is very suitable for residential areas is very limited, so expect optimal utilization.
\end{abstract}

Keywords: evaluation, land, MCE, suitablity, settlement areas.

(Diterima: 03-02-2017; Disetujui: 28-03-2017

\section{Pendahuluan}

\subsection{Latar belakang}

Pembangunan berkelanjutan merupakan proses pemanfaatan sumberdaya alam secara optimal dengan menyeimbangkan ketersediaan sumberdaya alam dan kebutuhan manusia saat ini tanpa mengabaikan kebutuhan generasi yang akan datang dalam pembangunan (WCED, 1987; Muta'ali, 2012). Pembangunan berkelanjutan memiliki tiga makna yakni pemanfaatan sumberdaya alam untuk memenuhi kebutuhan generasi sekarang tanpa mengabaikan kebutuhan generasi dimasa yang akan datang, pemanfaatan sumberdaya alam tidak melebihi daya dukung lingkungan, dan mengoptimalkan pemanfaatan sumberdaya alam. Baja (2012) menjelaskan bahwa pertumbuhan penduduk yang tinggi merupakan salah satu masalah dalam pembagunan berkelanjutan, karena pertumbuhan penduduk yang tidak terkendali akan menurunkan daya dukung lingkungan.

Pertumbuhan penduduk yang pesat akan mendorong perubahan penggunaan lahan antara lain untuk tempat tinggal dan fasilitas pembangunan. Luas daratan permukaan bumi relatif tetap sedangkan kebutuhan manusia akan ruang tempat tinggal terus meningkat seiring dengan peningkatan jumlah penduduk. Kodoatie (2013) jumlah penduduk dunia saat ini sekitar 7,045 milyar dan sekitar $6 \%$ diantaranya merupakan penduduk Indonesia. Angka pertumbuhan penduduk Indonesia periode 1950-2010 yakni sekitar $1,4-2,6 \%$ per tahun. Peningkatan pertumbuhan penduduk dari waktu ke waktu berdampak terhadap peningkatan pembangunan (Yunus, 2008). Pembangunan yang pesat telah menyebabkan perubahan pola penggunaan lahan. Fenomena tersebut umumnya terjadi pada wilayah perkotaan, dimana perubahan penggunaan lahan berlangsung dengan sangat dinamis (Pribadi et al., 2006). Kondatie (2013) menjelaskan perubahan penggunaan lahan akibat pengembangan permukiman yang tidak terkendali berdampak terhadap menurunya kualitas lingkungan.

Dinamika perubahan penggunaan lahan untuk permukiman dipengaruhi oleh pergerakan manusia dalam membangun permukiman serta pindahnya fungsi-fungsi wilayah, seperti pendidikan, industri, perdagangan, dan lain sebagainya (Kaur et al., 2004). Selanjutnya Pribadi et al. (2006) menjelaskan bahwa dengan pesatnya pembangunan akan menyebabkan perubahan pola penggunaan lahan, dimana ruang terbangun semakin mendominasi dan mendesak ruang-ruang alami untuk berubah fungsi. Hermon (2012) menjelaskan bahwa antara periode 1988-2014 di Kota Padang telah terjadi perluasan lahan lahan terbangun (permukiman) seluas 13.351 ha.

Pengembangan kawasan permukiman yang tidak sesuai dengan penggunaanya akan berdampak terhadap penurunan kualitas lingkungan dan mengakibatkan bencana alam. Penelitian Umar (2016) di wilayah penelitian menunjukkan sekitar 13 persen 
merupakan kawasan rawan banjir, dan sebesar 54 persen kawasan permukiman berkembang pada kawasan tersebut. Sedangkan, berdasarkan UU No 26 Tahun 2007 tentang Penataan Ruang menyatakan bahwa dalam penyusunan rencana tata ruang, terutama untuk kawasan permukiman, harus memperhatikan dan menghidari kawasan rawan bencana.

\subsection{Tujuan Penelitian}

Berdasarkan uraian yang telah disebutkan maka dapat dirumuskan tujuan penelitian ini untuk mengidentifikasi, menganalisis dan mengambarkan kesesuaian lahan untuk permukiman menggunakan metode Multi Criteria Evaluation (MCE) di Kota Padang.

\section{Metode}

\subsection{Lokasi dan Waktu Penelitian}

Lokasi penelitian ialah Kota Padang, Provinsi Sumatera Barat. Secara geografis, wilayah penelitian terdapat pada bajur $100^{\circ} 05^{\prime} 05^{\prime}-100^{\circ} 34^{\prime} 09^{\prime}$ ' BT dan lintang $00^{\circ} 44^{\prime} 00^{\prime}$ ' $-01^{\circ} 08^{\prime} 35^{\prime}$ ' LS. Wilayah penelitian memiliki luas 69.496 ha. Lokasi penelitian dapat dilihat pada Gambar 1. Penelitian ini dilakukan selama enam bulan, periode penelitian ini antara bulan April 2015 sampai dengan bulan September 2015.

\subsection{Prosedur Penelitian}

Metode Multi Criteria Evaluation (MCE) merupakan salah metode yang digunakan dalam analisis kesesuaian lahan dengan beberapa kriteria, penentuan nilai bobot dari kriteria disepakati secara bersama. Yang et al. (2011) dan Umar (2016) menggunakan metode AHP dalam penentuan nilai bobot dan harkat untuk kriteria. Penggunaan metode MCE dalam penentuan bobot kesesuaian lahan didasarkan ketidaksesuian parameter yang telah ada dengan karakteristik wilayah penelitian. Dengan melibatkan pakar dalam penentuan bobot diasumsikan akan menghasilkan parameter yang lebih sesuai, karena pakar lebih banyak tahun tentang karakteristik wilayah penelitian.

Kesesuaian lahan untuk kawasan permukiman berdasarkan USDA (1971), Hardjowigeno dan Widiatmaka (2007), Muataáli (2012), Hermon (2012), Umar (2016) yaitu: lereng, banjir, drainase, batuan kerikil, tekstur, dan kedalaman efektif. Sitorus (2004) kelas kesesuaian lahan untuk permukiman dapat dibedakan atas empat kategori, yaitu: sangat sesuai (S1), sesuai (S2), sesuai marjinal (S3), dan tidak sesuai (N). Untuk mendapatkan peta satuan lahan pada wilayah penelitian dihasilkan dari overlay beberapa peta tematik, yaitu: peta lereng, peta jenis tanah, peta bentuk lahan. Peta lereng dihasilkan dari Digital Elevation Model (DEM) menggunakan citra Shuttle Radar Topography Mission (SRTM) 1 Arc Second dengan skala $1: 25.000$. Peta jenis tanah diturunkan dari Peta Jenis Tanah (PPT) (1990) skala $1: 250.000$ yang diperbesar menjadi skala $1: 25.000$. Peta bentuklahan dihasilkan dari land system skala 1 : 250.000 yang dibuat oleh Regional Physical Planning Program for Transmigration (1990) diperbesar menjadi skala 1 : 25.000 . Hasil overlay ketiga peta tematik tersebut menunjukkan pada wilayah penelitian terdapat 24 unit satuan lahan.

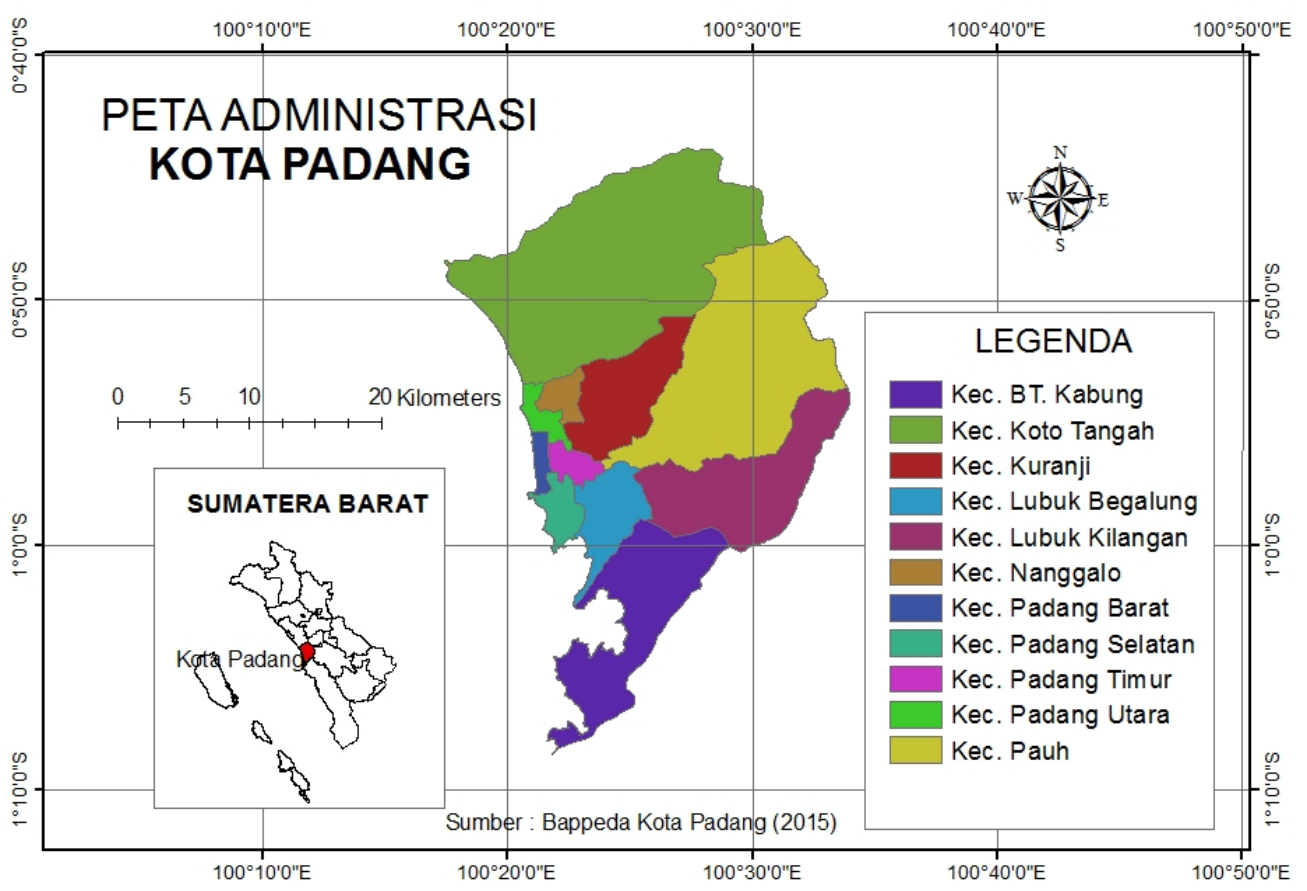

Gambar 1. Lokasi penelitian 
Penentuan bobot indikator kesesuaian untuk permukiman ditentukan berdasarkan pendapat pakar dengan menggunakan metode AHP (Analytical Hierarchy Process). Pakar akan menentukan penilaian yang berdasarkan skala 1 sampai 9 secara perbandingan berpasangan (pairwise comparision). Menurut Saaty (1983), Marimin dan Maghfiroh (2010) skala 1 sampai 9. Nilai dan definisi pendapat pakar dalam skala perbandingan ada pada Tabel 1 .

Tabel 1. Kriteria penilaian dalam AHP

\begin{tabular}{cl}
\hline Nilai & \multicolumn{1}{c}{ Keterangan } \\
\hline 1 & A sama penting dengan B \\
3 & A sedikit lebih penting dari B \\
5 & A jelas lebih penting dari B \\
7 & A sangat jelas lebih penting dari B \\
9 & A mutlak lebih penting dari B \\
$2,4,6$, & Apabila ragu-ragu antara dua nilai yang \\
8 & berdekatan \\
\hline \multicolumn{2}{l}{ Sumber: Saaty (1983), Marimin dan Maghfiroh (2010) }
\end{tabular}

Pakar yang digunakan untuk penentuan bobot pada analisis kesesuaian lahan untuk kawasan permukiman berasal dari Perguruan Tinggi, Dinas Tata Ruang Kota Padang, Bapedalda Kota Padang, Dinas Pekerjaan Umum Kota Padang, dan BPBD Kota Padang. Jumlah pakar yang digunakan untuk penentuan bobok kesesuaian lahan sebanyak 15 orang pakar. Untuk menentukan zonasi kesesuaian lahan untuk permukiman digunakan persamaan 1 , yaitu:

$$
I=\frac{c-b}{k}
$$

Keterangan

$$
\begin{aligned}
& \mathrm{I}=\text { besar jarak interval kelas } \\
& \mathrm{c}=\text { jumlah skor tertinggi } \\
& \mathrm{b}=\text { jumlah skor terendah } \\
& \mathrm{k}=\text { jumlah kelas yang diinginkan }
\end{aligned}
$$

\section{Hasil dan Pembahasan}

Hasil penilaian pakar dalam penentuan bobot terhadap kesesuaian lahan untuk kawasan permukiman (Gambar 2) menunjukkan bahwa nilai bobot tertinggi adalah drainase $(31,1 \%)$, sedangkan yang terendah yaitu batuan kerikil $(8,2 \%)$. Konsistensi penilaian pakar dalam penentuan bobot sebesar $96 \%$. Marimin dan Maghfiroh (2010) nilai inconsistency ratio yang dapat diterima adalah kurang dari 0,1 , dalam penelitian ini penilaian pakar memiliki inconsistncy sebesar 0,04. Artinya pakar cukup konsisten dalam melakukan penilaian.

\section{Model Name: Kesesuaian lahan untuk permukiman}

Priorities with respect to: Goal: Kesesuaian Iahan untuk permukiman

Lereng
Banjir
Drainase
Batuan kerikil
Tekstur
Kedalaman efektif
Inconsistency = 0,04
$\quad$ with 0 missing judgm ents.

Gambar 2. Hasil penilaian pakar terhadap bobot kesesuaian lahan untuk kawasan permukiman

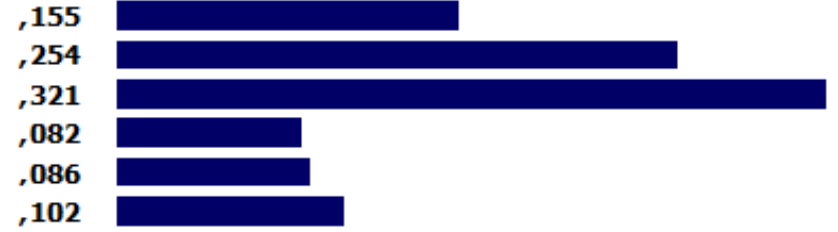

Gambar 2 menunjukkan bahwa nilai drainase merupakan penilaian bobot tertinggi untuk penentuan kesesnuaian lahan untuk kawasan permukiman di Kota Padang. Tingginya nilai bobot drainase berdasarkan pendapat pakar didasarkan kepada karakteristik wilayah penelitian, sebagian besar yang diperuntukkan sebagai kawasan permukiman berdasarkan pola ruang periode 2010-2028 memiliki morfologi relative datar (0-8 persen). Hal ini berarti dengan perbaikan drainase akan menurunkan banjir dan genangan saat musim penghujan. Karena Kota Padang sekitar 13 persen merupakan kawasan rawan banjir.
Tabel 2 merupakan kriteria yang digunakan untuk kesesuaian kawasan permukiman. Indikator yang digunakan untuk menentukan kesesuaian lahan kawasan permukiman yaitu: lereng, banjir, drainase, batuan kerikil, tekstur, dan kedalaman efektif. Hasil perkalian antara bobot dengan harkat akan diperoleh skor masing-masing indikator. Untuk menentukan zonasi kesesuaian lahan untuk permukiman digunakan persamaan 1. Hasil analisis diperoleh total skor tertinggi sebesar 323,5 dan total skor terendah sebesar 100 maka dengan empat kelompok kelas diperoleh interval sebesar 55. Tabel 3 merupakan kelas interval kesesuaian lahan untuk kawasan permukiman. 
Tabel 2. Kriteria kesesuaian lahan untuk permukiman

\begin{tabular}{|c|c|c|c|}
\hline Indikator/Bobot & Sub Indikator & Harkat & Skor \\
\hline \multirow[t]{4}{*}{ Lereng $(\%)(15,5)$} & $0-8$ & 4 & 62 \\
\hline & $8-16$ & 3 & 46,5 \\
\hline & $16-27$ & 2 & 31 \\
\hline & $>27$ & 1 & 15,5 \\
\hline \multirow[t]{3}{*}{ Banjir $(25,4)$} & Tanpa & 3 & 76,2 \\
\hline & Jarang & 2 & 50,8 \\
\hline & Sering & 1 & 25.4 \\
\hline \multirow[t]{3}{*}{ Drainase $(32,1)$} & Baik sampai sangat baik & 3 & 96,3 \\
\hline & Sedang & 2 & 64,2 \\
\hline & Agak buruk sampai terhambat & 1 & 32,1 \\
\hline \multirow[t]{3}{*}{ Batuan Kerikil $(8,2)$} & Sedikit & 3 & 32,6 \\
\hline & Sedang & 2 & 16,4 \\
\hline & Banyak & 1 & 8,2 \\
\hline \multirow[t]{3}{*}{ Tekstur/besar butir $(8,6)$} & $\begin{array}{l}\text { Agak Kasar (lempung berpasir, pasir berlempung, } \\
\text { pasir) }\end{array}$ & 3 & 25,8 \\
\hline & $\begin{array}{l}\text { Agak Halus (liat berpasir, lempung liat berdebu, } \\
\text { lempung berliat, lempung liat berpasir) }\end{array}$ & 2 & 17,2 \\
\hline & Halus (liat berdebu, liat) & 1 & 8,6 \\
\hline \multirow[t]{3}{*}{ Kedalaman Efekti f(10,2) } & Dangkal (<50c m) & 3 & 30,6 \\
\hline & Sedang $(50-90 \mathrm{~cm})$ & 2 & 20,4 \\
\hline & Dalam $(>90 \mathrm{~cm})$ & 1 & 10,2 \\
\hline
\end{tabular}

Sumber : USDA (1971), Muta'ali (2012), Hermon (2012a) dan Umar (2016)

Tabel 3. Kelas interval kesesuaian lahan untuk kawasan permukiman

\begin{tabular}{|c|c|c|}
\hline $\begin{array}{c}\text { Kelas } \\
\text { Kesesuaian }\end{array}$ & Kelas Interval & $\begin{array}{c}\text { Indeks Kesesuaian } \\
\text { untuk Kawasan } \\
\text { Permukikan }\end{array}$ \\
\hline $\begin{array}{l}\text { Sangat sesuai } \\
\text { (S1) }\end{array}$ & $266-324$ & $\begin{array}{l}\text { Zona permukiman } \\
\text { sangat sesuai }\end{array}$ \\
\hline Sesuai (S2) & $211-265$ & $\begin{array}{l}\text { Zona } \\
\text { sesuai }\end{array}$ \\
\hline $\begin{array}{l}\text { Sesuai marginal } \\
\text { (S3) }\end{array}$ & $156-210$ & $\begin{array}{l}\text { Zona permukiman } \\
\text { sesuai marginal }\end{array}$ \\
\hline $\begin{array}{l}\text { Tidak sesuai } \\
(\mathrm{N})\end{array}$ & $100-155$ & $\begin{array}{l}\text { Zona permukiman } \\
\text { tidak sesuai }\end{array}$ \\
\hline
\end{tabular}

Hasil analisis kesesuaian lahan untuk permukiman di Kota Padang menunjukkan bahwa terdapat sekitar 12.543 ha (18\%) zona lahan yang sangat sesuai (S1); terdapat seluas 52.390 ha $(75,4 \%)$ luas zona lahan yang sesuai (S2); seluas 4.279 ha $(6,2 \%)$ zona lahan yang sesuai marjinal (S3); dan sebesar 285 ha $(0,8 \%)$ zona tidak sesuai $(\mathrm{N})$ untuk permukiman. Distribusi zona kesesuaian lahan untuk permukiman dapat dilihat pada Gambar 3.

Pertumbuhan penduduk dan ekonomi pada suatu wilayah akan mendorong peningkatan pemanfaatan lahan untuk kawasan permukiman, sebagai akibatnya banyak kawasan permukiman berkembang pada zona yang tidak sesuai dengan penggunaannya (Burhanuddin, 2010). Penggunaan lahan yang tidak sesuai dengan penggunaannya dapat menimbulkan kerusakan lahan (Kumajas, 2006; Zakaria dan Hartono et al., 2015). Penggunaan lahan yang tidak sesuai dengan penggunnaanya tidak hanya berdampak pada kerusakan lahan, namun juga akan meninbulkan bencana alam dan degradasi lingkungan (Sumadikum 2007, Rachmat et al., 2014).

Kota Padang berdasarkan kemiringan lereng sebagian besar $(60 \%)$ merupakan wilayah dengan morfologi berbukit dan lereng yang sangat curam, hanya sebesar $30 \%$ yang layak untuk dimanfaatkan sebagai kawasan permukiman. Selain itu, tutupan lahan Kota Padang dibedakan atas enam jenis yaitu: (1) lahan terbangun/permukiman (16,5\%); (2) sawah (9\%); (3) kebun campuran (3,4\%); (4) semak $(0,6 \%)$; (5) lahan kosong (0,6\%); dan (6) hutan (70\%). Selanjutnya, jenis tanah berdasarkan PPT (1990) diklasifikasikan atas enam kategori, yaitu: (1) tanah Aluvial (13,8\%); (2) tanah Andosol (39,9\%); (3) tanah Latosol (25,5\%); (4) tanah Regosol (9\%); (5) tanah Organosol (0,3\%); dan (6) tanah Kompleks Podsolik Merah Kuning (11,5\%). Kota Padang berdasarkan penunjukan kawasan hutan dibedakan atas tiga, antara lain: (1) kawasan areal peruntukan lain/APL (30\%); (2) kawasan hutan lindung (24,5\%); dan (3) kawasan suaka alam (45,5\%). Berdasarkan karakteristik Kota Padang, maka lahan yang dapat dimanfaatkan dan dikembangkan sebagai kawasan permukiman sekitar $30 \%$ dari luas wilayah. 


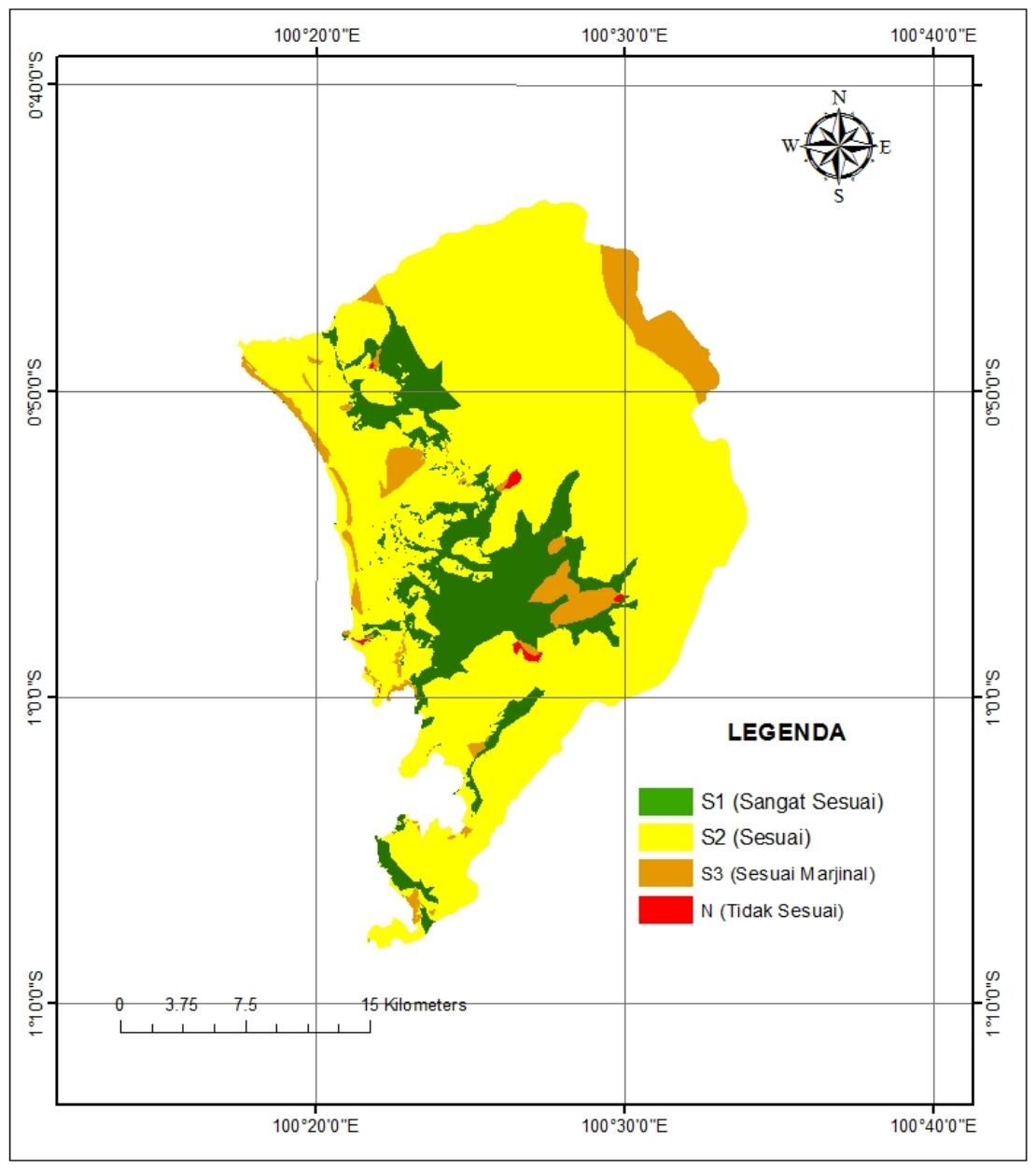

Gambar 3. Zona kesesuaian lahan untuk permukiman di wilayah penelitian

Kota Padang antara periode 2000-2014 memiliki tingkat pertumbuhan penduduk sebesar 1,4 persen/tahun, sebagai akibatnya bertambahnya luas lahan terbangun sebesar 16,5\% dari luas wilayah Kota Padang. Hasil evaluasi kesesuaian penggunaan lahan permukiman tahun 2014 menunjukkan seluas 3.824 ha $(33,3 \%)$ merupakan zona sangat sesuai (S1), sebesar 6.617 ha $(57,7 \%)$ kategori zona sesuai (S2), sesuai marjinal (S3) seluas 1.005 ha $(8,8 \%)$, dan tidak sesuai (N) seluas 21 ha $(0,2 \%)$. Hasil overlay peta kesesuaian lahan untuk permukiman dengan penggunaan lahan tahun 2014 disajikan pada Gambar 4.

Sadyohutomo (2008) mengungkapkan bahwa peningkatan jumlah penduduk akan mendorong peningkatan kebutuhan akan penggunaan lahan. Luas lahan yang dapat digunakan untuk mendukung kehidupan relatif tetap dan bersifat terbatas. Sebagai akibatnya, akan terjadi persaingan penggunan lahan dan pada akhirnya akan terjadi konflik antar pengguna serta penurunan kualitas lahan. Menurut Muta'ali (2012) bahwa pertumbuhan penduduk yang tinggi akan menyebabkan manusia memanfaatkan sumberdaya alam tanpa memperhatikan kemampuan dan daya dukung lingkungan. Sebagai akibatnya, terjadi penurunan kualitas lingkungan dan bencana alam. 


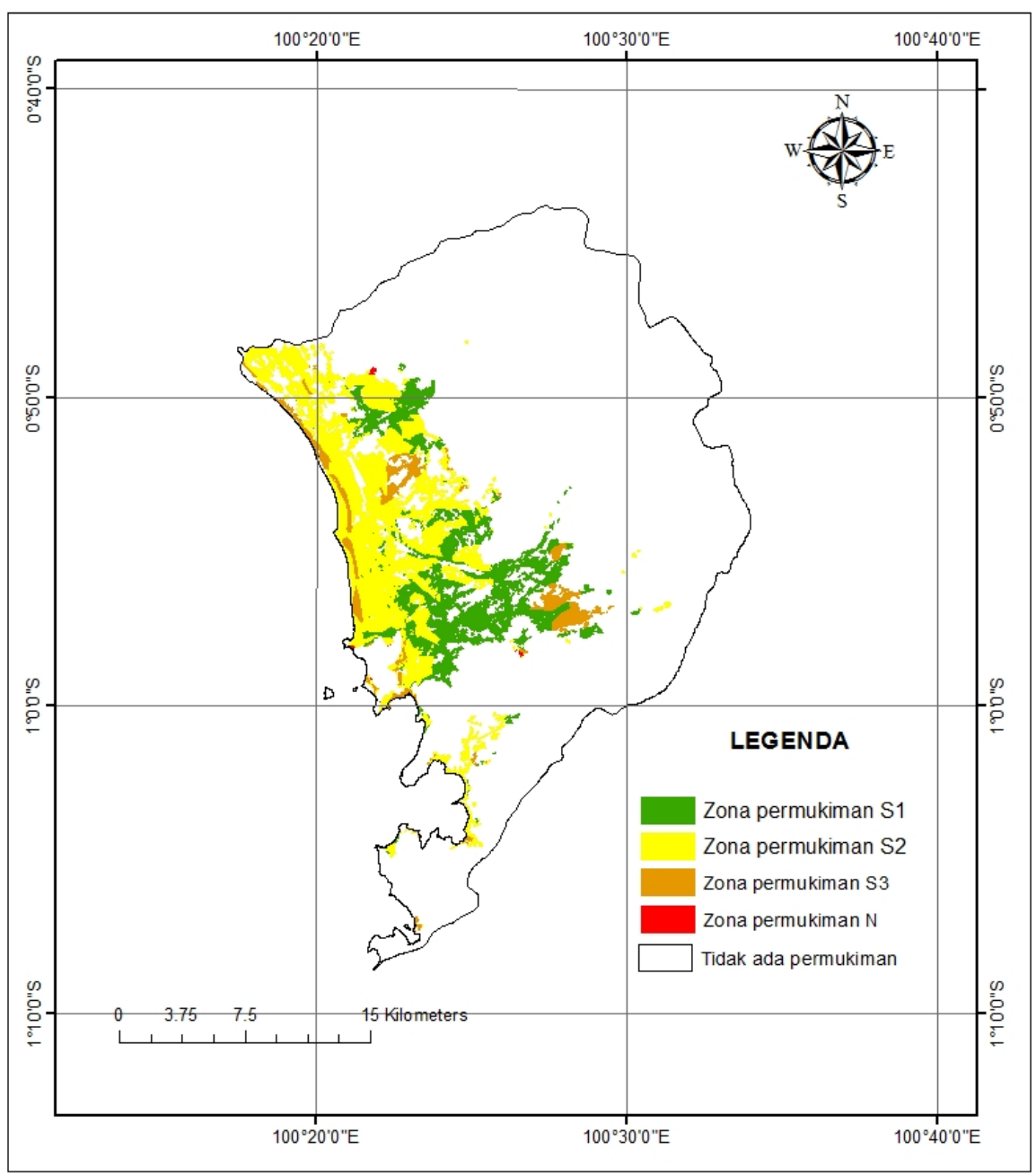

Gambar 4. Overlay kesesuaian lahan untuk permukiman dengan permukiman 2014

\section{Kesimpulan}

Kota Padang memiliki sekitar 30 persen kawasan yang dapat dikembangkan sebagai pengembangan kawasan permukiman. Kawasan pengembangan permukiman sebagai besar memiliki morfologi relatif datar, sehingga pada musim penghujan menimbulkan genangan dan banjir. Hasil penilaian pakar dalam penentuan bobot, nilai tertinggi yaitu drainase. Kota Padang berdasarkan evaluasi kesesuaian lahan untuk permukiman dengan menggunakan metode MCE menunjukkan bahwa seluas 12.543 ha (18\%) zona lahan yang sangat sesuai (S1). Selain itu, hasil overlay kesesuaian lahan dengan penggunaan lahan tahun 2014 terdapat sebesar 0,2 persen kawasan permukiman tidak sesuai $(\mathrm{N})$ dengan penggunaannya. Kawasan tidak sesuai karena memiliki kemiringan lereng lebi dari 27 persen.

Kepada pemerintah Kota Padang disarankan agar Dinas Tata Kota lebih selektif dalam mengeluarkan Izin Mendirikan Bangunan (IMB). Selain itu, kepada Polisi Pamong Praja agar lebih tegas dalam penindakan bangunan yang tidak sesuai dengan penggunaannya.

\section{Daftar Pustaka}

[1] [Perda] Peraturan Daerah Kota Padang .(2012). Rencana Tata Ruang Wilayah (RTRW) Kota Padang 2008-2028. Peraturan Daerah Nomor 4 Tahun 2012. Walikota Padang. Padang

[2] [PPT] Pusat Penelitian Tanah Bogor, 1990. Peta Jenis Tanah

[3] [RePPProT] Regional Physical Planning Program for Transmigration, 1990. Land System.

[4] [RI] Republik Indonesia, 2007. Undang-Undang No 26 Tahun 2007 tentang Penataan Ruang. Lembaran Negara RI Tahun 2007, No 68. Sekretariat Negara. Jakarta.

[5] [USDA] United States Department of Agriculture, 1971. Guide for Interpreting Engineering Uses of Soils. US. Dept. of Agriculture. Washington DC.

[6] [WCED] World Commission on Environment and Development, 1987. Our Common Future. United Nation World Commission on Environment and Development. Oxford University Pr. London.

[7] Baja, S., 2012. Perencanaan Tata Guna Lahan dalam Pengembangan Wilayah. Penerbit ANDI. Yogyakarta.

[8] Burhanuddin, 2010. Karakteristik Teritorialitas Ruang pada Permukiman Padat Diperkotaan. Jurnal Ruang, 2 (1): 39-46.

[9] Hardjowigeno, S., dan Widiatmaka. 2007. Evaluasi Kesesuaian Lahan dan Perencanaan Tataguna Lahan. Gadjah Mada University Press. Yogyakarta.

[10] Hartono, Anggoro, S., dan Buchori, I., 2015. Evaluasi Kesesuaian Lahan Permukiman Perum Bukit Persada Indah Kelurahan Purwoyoso Semarang. Jurnal Teknis 10(1), pp. 22-23.

[11] Hermon, D., 2012. Mitigasi Bencana Hidrometeorlogi.UNP Press. Padang. 
[12] Kaur, E., Palang, H., dan Soovali, H., 2004. Landscapes in Change-Opposing Attitudes in Saaremaa, Estonia. Landscape and Urban Planning 67(2), pp. 109-120.

[13] Kodoatie, R., 2013. Rekayasa dan Banjir Kota. Penerbit ANDI. Yogyakarta.

[14] Kumajas, M., 2006. Inventarisasi dan Pemetaan Rawan Longsor Kota Manado Sulawesi Utara. Forum Geografi 20(2), pp. 190-197.

[15] Marimin, dan Maghfiroh, N., 2010. Aplikasi Teknik Pengambil Keputusan dalam Manajemen Rantai Pasok. IPB Press. Bogor

[16] Muta'ali, L., 2012. Daya Dukung Lingkungan untuk Perencanaan Pengembangan Wilayah. Badan Penerbit Fakultas Geografi (BPFG) Universitas Gadjah Mada. Yogyakarta.

[17] Mutaáli, L., 2013. Penataan Ruang Wilayah dan Kota. Badan Penerbit Fakultas Geografi (BPFG) Universitas Gadjah Mada. Yogyakarta.

[18] Pribadi, D., Shiddiq, D., dan Ermyanila, M., 2006. Model Perubahan Tutupan Lahan dan Faktor-Faktor yang Mempengaruhinya. Jurnal Teknologi Lingkungan. Pusat Pengkajian dan Penerapan Teknologi Lingkungan 3 (1), pp. 77-91.

[19] Rachmat, AR., dan Pamungkas, A., 2014. Faktor-faktor Kerentanan yang Berpengaruh terhadap Bencana Banjir Di
Kecamatan Manggala Kota Makasar. Jurnal Teknik Pomits 3(2), pp. 178-184.

[20] Sadyohutomo, M. (2008). Manajemen Kota dan Wilayah Realitas dan Tantangan. Penerbit Bumi Aksara. Jakarta.

[21] Sitorus, S.R.P., 2004. Evaluasi Sumberdaya Lahan. Edisi Ketiga. Penerbit Tarsito. Bandung.

[22] Sumadikum, B.P., 2007. Dampak Pertimbangan Ekonomi terhadap Tata Ruang Kota Jakarta dan Bopunjur. Jurnal Presipitasi 2(1), pp. 34-38.

[23] Umar, I., 2016. Mitigasi Bencana Banjir pada Kawasan Permukiman Di Kota Padang Provinsi Sumatera Barat. (Disertasi). Sekolah Pascasarjana IPB. Bogor.

[24] Yunus, S.H., 2008. Dinamika Wilayah Peri Urban Determinasi Masa Depan Kota. Pustaka Pelajar. Yogyakarta.

[25] Yang, M., Qian, X., Zhang, Y., Sheng, J., Shen, D., dan Ge, Y., 2011. Spatian Multicriteria Dicision Analysis of Flood Risks in Aging Dam Management in China. International Journal of Enviromental Research and Public Health 8(5), pp.1368-1387.

[26] Zakaria, Z., 2009. Analisis Kestabilan Lereng Tanah. Laboratorium Geologi Fakultas Teknik Geologi Universitas Padjadjaran. Bandung. 